Portland State University

PDXScholar

10-24-1972

\title{
Continuity of a Traditional Social Pattern: the "Man- Patron" Relationship in Contemporary Northeast Brazil
}

Patricia Ellen Thorpe

Portland State University

Follow this and additional works at: https://pdxscholar.library.pdx.edu/open_access_etds

Part of the Family, Life Course, and Society Commons, Nature and Society Relations Commons, and the Social and Cultural Anthropology Commons

Let us know how access to this document benefits you.

\section{Recommended Citation}

Thorpe, Patricia Ellen, "Continuity of a Traditional Social Pattern: the "Man-Patron" Relationship in Contemporary Northeast Brazil" (1972). Dissertations and Theses. Paper 958.

https://doi.org/10.15760/etd.958

This Thesis is brought to you for free and open access. It has been accepted for inclusion in Dissertations and Theses by an authorized administrator of PDXScholar. Please contact us if we can make this document more accessible: pdxscholar@pdx.edu. 
AN ABSTRACT OF THE THESIS OF Patricia Ellen Thorpe for the Master of Arts in Anthropology presented October 24, 1972.

Title: Continuity of A Traditional Social Pattern: The "Mian-Patron" Relationship in Contemporary Northeast Brazil.

APPROVED BY MEVBERS OF THE THESIS COMMITTEE:

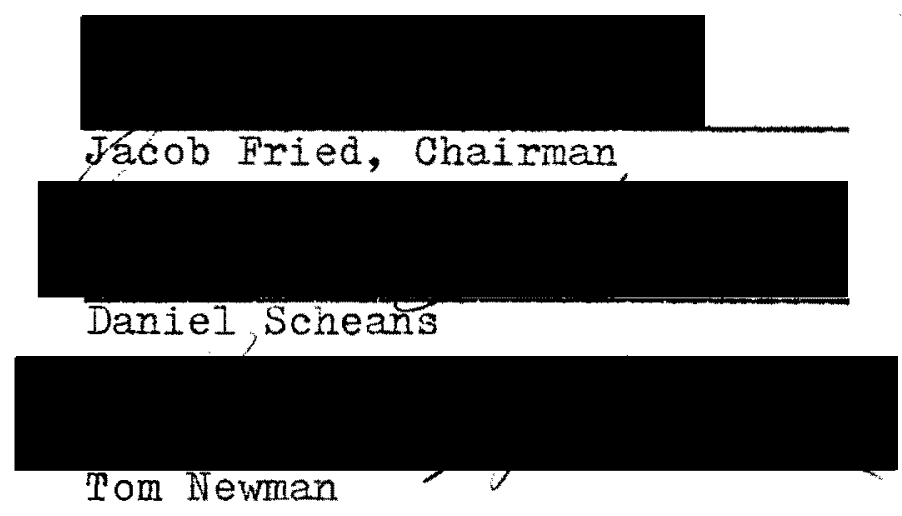

Northeast Brazil is a region characterized by economic poverty and human misery. Poor ecological conditions contribute to the nature of the dilemma, but another factor in the apparent cultural stagnation of the Northeast, may be the persistence of values and social practices traditionally aligned with the colonial sugar plantation system. Thus, this thesis represents an examination of the continuity of a given pattern, the man/patron relationship. This pattern is a contemporary parallel to the master/slave relationship which was the key to understanding of the social system of the colonial period. An historical overview reveals the 
nature of the traditional system, which proceeded to decline in the late nineteenth century. A review of present day conditions of the rural worler in the Northeast indicates numerous aspects of the colonial system which remain almost as they were. This review is followed by several case studiss hich particularly reveal various manifestations of the man/patron pattern in contemporary situations other than those associated with the remaining sugar industry. The inforination presented in the case studies was collected in 1968-69 when the author was living in Recife on a Fulbright-Hays grant. The case studies do not represent conclusive documentation but, rather, provocative evidence that certain aspects of the traditional social systen, namejy the man/patron pattern, persist in a contemporary society which is no longer solely dependent on nor dominated by the production of sugar. Furthermore, the thesis inglies that the continuity of traditional cultural patterns may, in fact, obstruct efforts of economic and sosial development. 
CONTINUITY OF A TRADITIONAI SOCIAI PATTERN:

THE "MAN-PATRON" REIATIONSIIP IN CONTEMPORARY NORTHEAST BRA.ZII

by

PATRICIA ELIEN THORPE

A thesis submitted in partial fulfillment of the requirements for the degree of

MASTER OF ARTS

in

ANTHROPOJOGY

Portland State University

1972 
IO PE OPETOA OF GRADUATE STUDTES:

Ta merbers of the Committee approve the thesis of

Qutriola Blien Thorpe presented October 24, 1972.

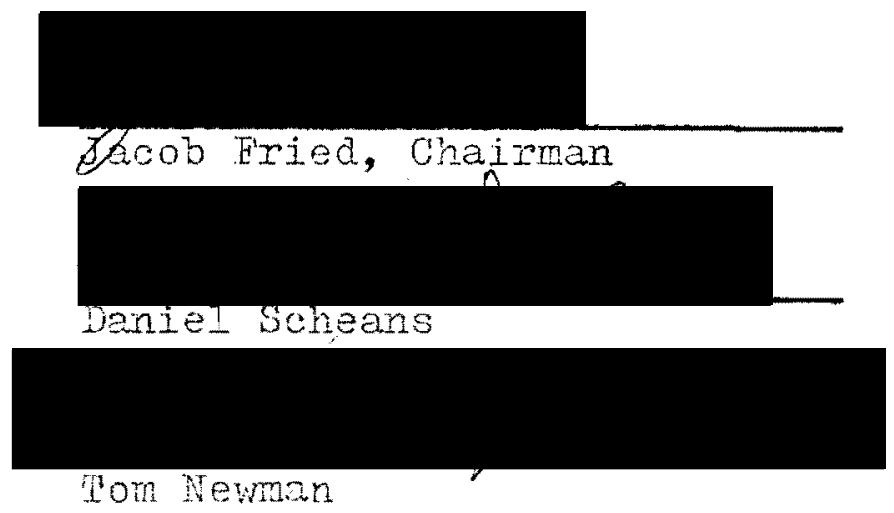

ATPROVED:

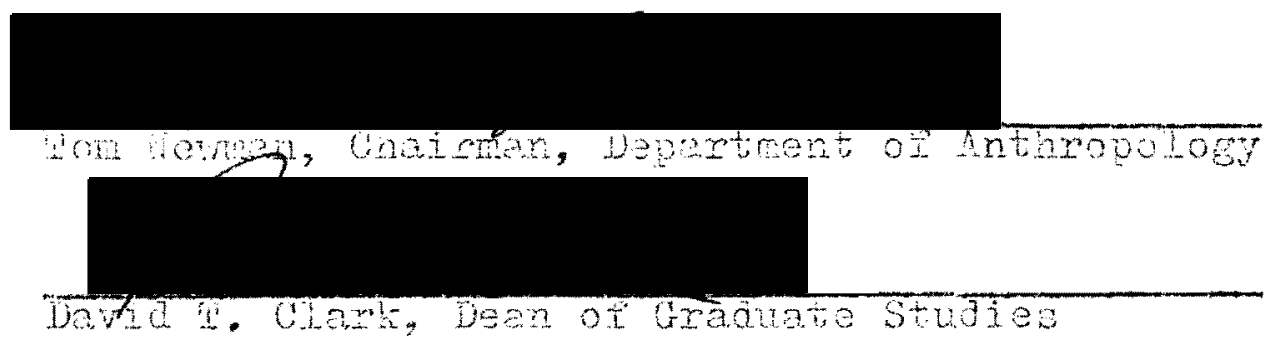

00606022,1972 


\section{ACKNOWLEDGENENTS}

I would like to acknowledge the Fulbright-Hays grant which permitted me to pursue my anthropological interests in Brazil during 1968 and 1969.

I would further like to thank the faculty members of the Anthropology Department at Portland State University for their help and contributions. I am especially grateful to Dan Scheans, Tom Newman, and Jacob Fried for their continual advise, chastisement and moral support.

Lastly, I salute my parents and family whose understanding and irsistence that I would survive greatly encouraged me throughout the entire effort. 
TABLE OF CONTEHTS

PAGE

ACRIOWJEDGELETS . . . . . . . . . . . i ii

CHAPTER

I THE PROBLEM AND ITS CULTURAL BACKGROUND . . 1

The Historical Overview . . . . . 6

II THE TRADITIONAI PIANTAIION SYSTEM: NORTHEAST BRAZIL . . . . . . . . . . . 11

III POST ABOLITION: THE RECENT PAST . • . . . 24

IV CASE STUDIES . . . . . . . . . . 42

Case Study $\# 1$.......... . 43

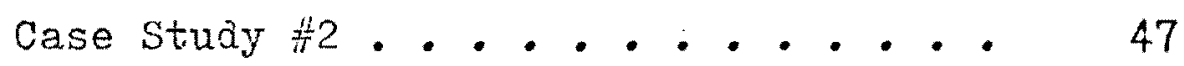

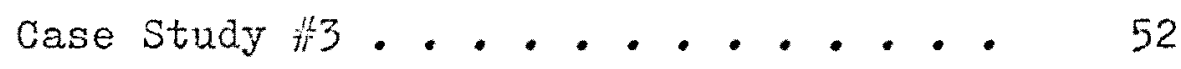

V CLOSING COMHENTS . . . . . . . . . 57

BIBLIOGRAPHY . . . . . . . . . . . . . . 61

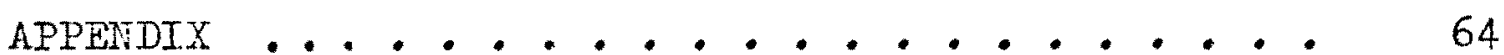




\title{
CHAPTER I
}

\section{THE PROBLEM AND ITS CUIMURAL BACKGROUND}

\author{
Introduction
}

The aim of this study is to examine one aspect of the traditional colonial sugar industry and plantation system, the man/patron relationship, and its expression in contemporary Northeast Brazilian society. It is, therefore, a study of culture change and persistence as seen in the transformation of the sugar industry, a socio-economic configuration that dominated the tropical regions of the Americas between 1550 and 1900. After that time, mechanization and moderitzation severely affected the sugar industry and its associated plantation system. Hagley and Harris discuss this change process in a study of Latin American subcultures and they coment as follows (Heath; 1965:52):

\footnotetext{
- . at least two broad types, the Engenho Plantation and the Usina Plantation subcultures, may be found throughout Latin America. No matter what crop the plantation produces, there has been a transition froin the old traditional enterprise to the modern industrialized establishment analogous to that which has taken place in sugar production. Everywhere this transition has involved a shift from a more personal and stable set of relations between the classes to a movile, impersonal one based on economic values and urban standards. It has involved a change from a. smill and relatively homogeneous society to a larger and more variegated one; and it has led to a more important role for national institutions and patterns on all levels of plantation life.
}

However, while in different places, similar events, such as 
abolition and industrialization, greatly modified much of the New World plantation system, Northeast Brazil appears to be an exceptional region where aspects of the traditional culture persisted despite the progressive decline of the colonial system. Indeed, Hutchinson (1956:6) could have had this area in mind when he wrote that the

- . influences of the nineteentr and twentieth centuries have not been felt with equal intensity throughout the American suzar producing refions. In limited areas, large sugar mills owmed and operated by powerful corporations with veritable factory tows may be found. In other sugar producing areas the transition is less complete and many patterns out of the traditional past of the areas have persisted and have been adjusted to the new conditions.

What happened in Brazil, and elsewhere in the sugar growing regions of the Nev World, represents a synthesis of new production methods with the system which preceded it. Accordingly, Mintz states (1956:315):

The present day culture of the area must be seen as a result of the cultural synthesis of the pre1900 patterns and the subsequent innovations into a new way of life.

Abolition and the declaration of the Republic catalyzed the formation of new political policies and conceptualization of national social and economic goals. These, in turn were introduced into a cultural context enveloped in decades of colonial control. It follows that the epoch of social, political and econoinic prominence of the Northeast relates to that colonial period when sugar provided the crux of the Portuguese bid for eminence in the world trade market. Since the decline of the sugar industry, however, in the late nine- 
teenth century, the Northeast has been largely ignored as a viable economic resource. Both economic and social development were retarded until the 1960's when perhaps, one could venture, the future regional potential of the Northeast was recognized. Foreign aid funds and development programs focused on this area during the past decade. However, the efforts have accented the fact that the potential is more accurately hoped for than ascumed, for the salient feature of the Northeast is not its obvious possibilities for the future, but rather its grim status of the present. As an area plagued by drought and populated by masses of undernourished, uneducated and generally propertyless persons, the outstanding characteristic of the Northeast is the incredible noverty and the lack of provision to deal with the prevalent huran dilemmas of unemployment, lack of food and poor health facilities, etc.

Therefore, in discussing synthesis of new methods with a preceding systern, Northeast Brazil represents a region in which the influences from the past are very significent in shaping the present culture. But, it is not the antiquity of the preceding system per se that wields the greatest effect on any change, it is the relative stability of the existing system which determines how receptive or resistant to change a given system will be. For example, in examinirs the social organization associated with Brazilian sugar plantations during the colonial period, one must consider how closely certain key variables function 
in terms of integrating the entire system, as well as the ways in which the integrating factors are reinforced in terms of daily behavior.

If we accept the premise that today's culture is a synthesis of old and new, the task is to discover where the respective features intersesh. Specifically, therefore, this thesis undertakes to examine the master/slave relationship in the context of the colonial sugar plantation system and then in the contemporary social system of the Northeast. I hypothesize that this relationship was the key to the maintenance of the culture which characterized Northeast Brazil throughout three hundred years of sugar production. The relationship became deeply embedded in the social structure and, inspite of the fact that the economic basis for the relationship has since declined (family owned, slavelabor plaxtations) as a result of abolition and accompanying changes, the master/slave or man/patron relationship continues to be instrumental in determining the nature of interpersonal relationships in contemporary society. To clarify this point, the man/patron pattern can be defined as a social pattern derived from establishing a social or business relationship in terms of the values and practices which traditionally governed the naster/slave syndrome; the "master" had property, family name, wealth, education, political ascoeiations; the "slave" was a servant to the master, had few personal possessions, no property to speak of, and little, if any, education. This then was the theme 
of the social stmucture in the plantation era--there were slaves and there were masters, and as if these statuses were ascribed at birth, even after the abolition of slavery, the persisting association of values characterizing each role continued to shape the nature of social interaction in the Northeast.

It is imperative to understand this phenomenon if one intends to interpret or promote change in the Northeast. New social patterns accompanying new social and economic institutions may overlie the traditional system, but certain traditional patterns, particularly the master/slave or man/patron syndrome continue to function as viable elements in present day society. To demonstrate this, I shall first discuss the master/slave relationship in its historical context in Brazil and then present examples of how the configuration of traditional values persists as an influence in not only the present day sugar industry, where one might logically assume it continues, but show, furthermore, how, as a significant feature of the social organization for several centuries, the master/slave relationship influences social situations in contexts other than those directly connected with the growth and manufacture of sugar. In sum, the master/slave relationship was the key to the traditional. social system in the Northeast. And what I refer to as the man/patron pattern, and variations of it, is a sequel to the traditional master/slave syndrome. It is thus essential, in attempting to analyze or conduct social and business 
relationships in the Northeast, that one perceive the nature of the man/patron relationship and acknowledge its persistence and its manifestation in contemporary society.

\section{THE HISTORICAL OVERVIEW}

If one envisions the transformation of family ormed, slave labor plantations to corporate owned, wage labor operations, ore might logically suspect that the process would involve the eventual disintegration of the traditional social organization based on the existence of masters and slaves. Indeed, as both mechanization and abolition contributed to the decline of the plantation system, it followed that former slaves becan:e property owners and previously resident masters managed to operate their automated refineries in absentia. But, as change proceeds at a differential rate, depending on elements in the culture, one might also rightfully expect a variety of social and economic transformations throughout the sugar growing regions of the New World during the last of the nineteenth century.

This thesis focuses on Northeast Brazil, because a study of the "sugar culture" reveals and indicates a notable case in terms of cultural continuity. Accordingly, and with respect to the Northeast, Hutchinson comments (1957:4):

The cultivation of sugar cane, over a period of two hundred years or more, developed into a remarkably stable way of life. For centuries, the sugar industry was a Iamily enterprise, based on slavery, and generation after generation exploited the same plantation with the same crop, to which they developed a strong loyalty. 
Indeed, power and prestige became closely identified with ownership of large tracts of land and involvement in the sugar industry, and, in some instances, families have maintained control of their inherited interests in the face of changes wrought by mechanization and abolition. In the Northeast, modern sugar factories are commonly family corporations and the supply of raw sugar continues to come from individual, family owned plantations which have conserved their original boundaries. Owners of these plantations are often descendents of the aristocratic landholders of the past and many of their workers are descendents of slaves who lived on the same plantation (Hutchinson; 1957:8). Although, as in Puerto Rico and the southern United States, the sugar industry in Brazil was exposed to innovations in planting and refining methods in the late nineteenth century, there was definitely a continuation of the plantation tradition in the Northeast, whereas in the other areas, sugar production was almost completely transformed into big business, corporate operations. Perhaps, the greater amount of capital investment available to Puerto Rico partially explains the more extensive transition of techniques and labor arrangements there than in Brazil. On the other hand, studies by Elena Padilla Seda (Steward, 1957) and Sidney Mintz (Steward, 1957) indicate that this one variable certainly can not explain the great contrast between the Northeast and Puerto Rico, for despite the historical similarities in terms of the structural emposition of colonial sugar plantations, 
certain behavior patterns and attitudes distinguish Brazil from the beginning. This is largely a reflection of Portuguese heritage and the nonviolent manner in which the Portuguese colonized the Brazilian territory (Castro; 1966:65).

In Northeast Brazil, the period of Portuguese colonization was not preceded by an indigenous agrarian society. On the contrary, the region was unevenly populated by Indians who were hunters and gatherers and, in some cases, limited horticulturalists. Essentially, the Portuguese discovered a virtually uninhabited expanse of virgin land and their initial contacts with the local population consisted of trading trinkets for Brazilwood. A classic statement from Josue de Castro (1966:68-69) reports that:

According to what has come down to us: the Indians had already passed beyond the upper stages of savagry and arrived at the lower stage of barbarism in Lewis Morgan's terminology. They knew how to make pots and weave nets; and when they were not on the move, they practiced a rudimentary agriculture based on manioc and corn, from which they obtained a number of foods, particularly manioc meal, a food requiring a relatively complicated preparation.

Apparently, the Portuguese tried to maintain trading relationships with the Indians in order to insure their laborious efforts in supplying the wood products which were the most important trade goods of the time. However, reciprocal agreements between the Portuguese merchants and the Indians began to deteriorate in 1532 with the Crow's issuing royal land anants to the Portuguese nobility. From then ch, Castro reports (1965:71) Indians were sought as slaves, for with the advent of the land grants, the Portuguese became seriously 
involved in colonizing Brazil, and besides bartering raw materials from the natives and shipping them to Europe, they began to clear and work the land itself. In addition, the Portuguese ecconomy, during the sixteenth century, was in poor condition relative to other European mercantile nations. Dutch nercantilists increasingly dominated vorld commerce, and the Portuguese, although they had discovered a potentially vast resource in Brazil, were comparatively ill-prepared to develop and profit from their good fortune. Portugal had few human or material resources available for colonization of such a great territory, which perhaps is one reason why the Dutch eventually challenged the Portuguese hold on Brazil in the early part of the seventeenth century. The Brazilian colony bocame an expecially rich resource when the Northeast began to supply sugar to the world market. In sum, the Portuguese settled Brazil in order to fortify their weak position in the European mercantile system and in doing so, transported to Brazil the feudalistic agrarian system which had functioned in Portugal for centuries (Castro; 1965; Southey; 1822:Vol. I). As such, Brazil represented an extension of Portuguese society, and the Northeast, in particular, was the center for the aristocratic society descended from Portuguese nobility. It was this group of persons who received royal land grants from the Crown, and, who in turn, became the masters of the emmense sugar plantations, which, in Erazil were inom as enconhos. The ensuing development and stabilization of the sugar plantation system led to what Leeds referred to as the "static 
asrarian soniety" (1964:1331). Whereas, Portugal proceeded to keep step with most technological advances originating in Europe, Brazil remained an agrarian state characterized by many cultural features inherited from medieval Portugal. This sequence of events is particularly represented by the Northeast, where, despite recent and intensive efforts to industrialize and economically reform the nation as a whole, this region has remained traditional. This subsequent conservatism, or as some say, backwardness, can partially be accounted for by several other factors, too. First of all, the region is geographically isolated--especially from other areas of Brazil, such as Rio de Janeiro and Sẩo Paulo. These are the areas undergoing the most change. Between the Northcast and these urban, industrial contcro, commuications and transportation connections are still very inadequate, and, in some places, do not exist at all. Furthermore, the dire ecological conditions of the Northeast make the area very unattractive for new settlement and investment. So, although this area thrived during the height of the Brazilian sugar empire, the region has failed to remain a viable contributor t;o the national economy since the end of the nineteenth century. 
CHAPTER II

\section{THE TRADITIOHAL PIANTATION SYSTEM: \\ NORTHEAST BRAZIL}

Fortuguese colonization of Brazil was exploitative, for although they did not extract minerals, at first, as did the Spanish in their colonies, the exportation of sugar from the Northeast constituted a valuable treasure to the mercantile economy of Portugal. Even today, one can see that little was contributed by the Portuguese in terms of architectural aesthetics or art and handicrafts. Perhaps the mich follolore of the Northeast depicts best the cultural legacy from the colonial period. It remains largely unwritten except for the literary contributions of the Northeastern authors such as José lins de Rêgo, José America de Almeida Eudides da Cunha, and Gilberto Freyre and Jorge Amado. It is through these accounts as well as historical documents that the stonies of severe droughts and the pervading influence or the sugar plantations system repeatedly tell of the suffering in the Northeast. The wealth from the sugar always remained in the hands of a few families, with little dissemination to the majority of hurnan beings involved in the industry; the ecological conditions affected everyone (Castro, 1965).

The plartation system in Brazil was similar, in general design, with those of the other sugar growing regions in the 
tropical Americas. The distinctive characteristics of this system are described as follows (rintz; 1956:330):

1) the functions of laborer and employer were sharply distinct; 2) the system was based on commercial agriculture, except in periods of depression; 3 ) the system vas representative of a capitalistic stace of arricultural development since the value of slaves, land and equipment necessitated the investment of money capital, often in laree amounts and frequently borrowed, and there was a strong tendency of the planter to assume the attitude of a business man in testing success by the ratio of net money income to capital invested; 4) there was a repeated trenc towerds specialization--the production of a single crop for market.

In conclusion, one historian has asserted (Mintz; 1957:330):

- . the genesis of the plantation system is to be regarded as a phase of colonial expansion of capitalism necessitated by the industrial environment peculiar to certain parts of the New World, the character of the races and population that entered into the fabric of the colonjal empire, the commercial and colonial ideas of the several nations participating in the task of colonization and the technical character of industry at that period.

In Brazil, this colonial sugar industry developed in the Northeast, where the land along the coast, in what are now the states of Baria, Alagôas and Pernambuco, is well suited for the cultivation of cane. It was in this region, known as massape, that the distinctive Brazilian engenhos were established. Ferhaps Gilberto Freyre, a Brazilian sociologist and novelist, has written the most well known account of the sugar nonoculture of the Northeast and the characteristic engenhos (1936). He writes of the relations of the masters in their "big houses" (casas grandes) with their slaves in their "huts" (senzalas) and of how the sugar industry shaped the nature of Brazilian culture. Other Brazilian historians 
such as Antonil (1950), Hollanda (1948), Castro (1965), and Wanderly (1946) have also written of the conditions and circumstances of colonial life in the Northeast. Collectively, they present a picture of a stable, tradition-bound society based on wealth from sugar, and, in sum, the history of the liorthcast depicts a society in which the few aristocratic land-holding and slave-owning families dominated the poor, laborine masses economically, socially and politically. In the words of Josué de Castro (1965:65):

The sugar culture of the Northeast institutionalized white aristocracy in the role of seignor and principally over the black as slave. It established the house as mansion and degraded the workers hut into a slum. It gave value to the cane fields and the rest of the land became contemptible.

The destruction of the forests or fields and the otherwise total domination of the sugar industry over the nature of the Northeast assured the subordination of all resources to the aristocratic rule of the sugar planters and the merchants who marketed the sugar abroad.

How can one describe the actual domaine of the sugar planters who were called senhores de engenho? Perhaps one of the best accounts of what an engenho generally consisted of is offered by Wagley and Harris (1965:49-50):

Although there were local differences, sugar cane plantatjons during the period of slavery seem to have folloved a similar pattern throughout the area. The center of the plantation, and the community or neighborhood which it formed, was the mansion in which the owmer, his large fanily and the many domestic servants lived. A chapel, which was either attached to the mansion or situated near it, served as a church for the owmers and for the slave workers. Behind the mansion were 
the slave quarters--a street of huts. Nearby there were sheds used to store tools and equipment and to house the oxen and the other animals. A storehouse, where the food and other supplies for the field hands were kept and periodically distributed, was also a cormon feature. Then, nearby, there was the engenho which was a small sugar factory containing a mill driven by hand, by animal traction, or by water power. Such plantations were generally situated on water ways which furnished easy transportation to market centers. Characteristicaily the plantation settlement pattern was a concentrated one resembling that of a small village.

They further add,

The number of people on such plantations was generally not large during the slave period. On the average, no more than 200 to 300 people lived on a relatively large plantation, and within this small "village-like" society, social relations tended to be intimate and highly personal. The members of the owners family were tied together into a large, extended patriarchal group. Between these aristocrats and slaves there was a stable set of relations often accompanied by personal intimacy and intense loyalty. It was in other words a "caste" society made up of liegro slaves and suropean owners in which each caste vas conscious of the rights and obligations of the other. Isadership was provided automatically by the dcminant European group, and economics, religion, and almost all aspects of life were directed and controlled by the aristocratic owner or his administrators.

In addition, there are several quotes from historical documents which I vould like to include in order to amplify the above aescription. It is difficult to perceive how exclusively the natural and human resources were devoted to the cultivation and processing of sugar in Northeast Brazil. There are in fact many prosaic passages written about sugar, attributing to cane qualities of regalness--the point being that sugar was the focus and source of almost all livelihood in the Northeast for approxirately three hundred years. The followins quote provides further information about engenhos 
which emnasizes this point (Southey; 1822:674):

- . the production of sugar was the chief object to which the inhabitants of the coast applied themselves. An engenho could not be well conducted unless artificers in every trade necessary for its concerns were attached to the establishment. Every engenho, therefore, was a community or village in itself, more ponulus at this time than many of the towns which have been enumerated. About eight square miles were required for the service of an engenno, half in pasture, half in thicket and woodland. A donatary would give land to any person who would settle on it and grow cane, which they were to carry to his mill for a fair price; and he would pay them for carmying wood there. In the large engenhos from fifty to one hundred Negroes were employed.

With regard to the type of "masters" who owned the sugar plantations, Koster, a British traveler, who wrote a graphic travel diary, comments the following (Southey; 1822:780):

- . the Pernambuvans appealed to the achievements of their ancestors as conferring upon them the proud distinction among other Brazilians; and the representative of the great femilies, tho han distinguished themselves in that tremendous struggle, (the Dutch war) had the true character of nobility. Everything had an air of permanence about their estates. None of the slaves were even sold. . . from a feeiing too noble in its nature and origin, and too beneficial in its effect to be called pride, though pride mingled with it.

With respect to the slaves, Koster remarked:

In a state of slavery, it is a blessing thus to be attached to the soil. The slaves in these circumstances had all the comforts which they reouired in such a climate: their huts were neat, they had their gardens, in which they cultivated bananas and tobacoo; and they reared pigs and poultry. Those who were born upon the estate were sometimes permitted to add one of the family names to their own even if they were not attached to their master, they were proud oi the family to which they belonged. . . This vatemalism on the part of the masters was reciprocated by the slaves with a feeling of loyalty and Erateful subjugation.

No doubt, Koster was influenced in his interpretations by his upper class hoste, who sought to show him the good-side 
of the plantation system. However, despite the fact that there are counter reports of abusiveness and contemptible practices regarding slave treatment, in general, the historical documents indicate a strong familial-type bond existed between many slaves and their masters. This sense of fidelity and servitude which so often characterizes the Brazilian slave on the plantation is also reported with respect to slaves belongine to persons other than sugar planters (Southey; 1822:782):

- upon the great family estates, slavery has something of a feudal characteristic. Among the small proprietors, who are mostly people of color, it is alleviated, as it is among the orientals and among the sevores, by the pariety of conditions, in all other respects between the master and the slave. They work together and fare alike and this equality induces a sense of honorable pride in the slave; he enters into the interest and the feelings of the family of which he is a member and will not suffer a word to be spoken against his master without resisting it.

Koster is essentially reporting that even where there were no physical and ancestral differences between master and slave, as was the case on the large plantations, the master/ slave relationship still involved a sense of subservience on the part of the slave and a sense of paternalism on the part of the master which were tempered with a close and even intimate pattern of interaction.

The following accounts describe the conditions of slaves who did not have benificent masters, and perhaps Freyre had such circumstances as the following in mind when he stated (1936:Iiv) that the worst features of the 
old system have persisted to this day still causing misery

for the bulk of the population. Accordingly, Koster reports:

The character and description of the owner may be plainly understood by the appearance of the slaves; upon estates where the proprietor is not resident, or which are in the hands of a speculator of little or no capital. . . The Negroes have neither time, nor strength now heart to provide any comfort for themselves. The usual routine is that the slaves besin work at six o'clock, and continue till half past five or six, with intervals of half an hour before breakfast, and two hours at noon. Sometimes there is homework, for an hour or two after the rield labor; and in crop time, which is from four to six months they work through the night as well as the day, being relieved every six hours. The slave receives in the year two shirts and two pair of drawers and perhaps two straw hats; he has a mat to lie on, and a piece of baize for a coverlet. If the master reeds him instead of allowing him the Saturday for raising his own provision, his food consists of manioc flour and beef jerky or salt fish: the Saturday's work, even with the aid of holy days, is not sufficient, unless he works for his master by the piece, and is thus ensbled to win time for his otm use. Instances of abominable cruelty sometimes occur in the treatnent of slaves; but they are less frequent than in former times and excite a very general feeling of indignation and abhorrence. It is observed, that slaves, when made overseers, are more unmerciful than the free men ano men from Europe than natives of the land; that women are more cruel to their slaves than men.

I shall include some further details on the nature of slavery because certain aspects of the conditions surrounding slavery in the colonial period are relevant to the nature of the man/ patron relationship as expressed in contemporary society. To continue, therefore,

The law which empowers them to purchase their ow freedom, is sometimes set at nought by the master; but not frequently, for by doing so, the public opinion is offerced. A slave, mo is cxerting himself for this purpose, is always distinguished by his industry and. steady conduct. In large town many slaves are employed as handicrafts, boatmen or porters, paying to their owners a certain sun weekly. Sucin men, if they do not 
fall into evil habits, to which their way of life exposes them, may redeem themselves in ten years, allowing for their necessary expenses, and something for indulence. Female slaves are less able to provide for their redemption, but they are not wholly without means; they make sweetmeats and cakes for sale, and some of them are hired out as domestic servants. Many are emanoinated at the death of their owers, and rich proprietors generally set some at liberty during their lifetires. The woman who shall have reared ten chilaren, is declared free, by a law more benignant in appearance than in reality, because its benefits can extend to very few; and it becomes the keenest aggravation of the keenest sense, when the parent forfeits her clain to liberiy because of the death of her child. A more effective law, worthy of introducing wherever the abomination of slavery is permitted, provides, that the owner shall manumit an infant at the font, if any person offers twenty milreis, as the price of its freedom. Free men frequently emancipate their illegitimate offspring in this manner; and it is not uncommon for the sponsors thus to confer the greatest of all benefits upon the babe for whom they pledge themselves. In the hope of this, a bondswoman sometimes requests persons of quality to become sponsors to her child; thinking that either at the ceremory or at some future time, from feelings of kindness or of dienity; they will rot suffer their godchild to remain a slave; . . . for this tie is highly regarded in Brazil.

What seems very clear in characterizing the relationship between masters and slaves is the sense of noblesse oblige exhibited by the aristocracy and no less catered to by the slaves. There was definitely a system of reciprocity, for whereas the slaves vere the possession of their masters and dependent upon them for their entire welfare, the sugar planters, one rnust remember, could never had succeeded without the labor provided by slaves . . there was, in this respect, a mutual dependence, and perhaps many plantation owers fully rocowizod that it was in their interest to maintain their slaves relatively well. Slaves definitely did well to cultivate lavorable relations with the master, for escape many 
times offered a much worse existence than within the protective confines of a benevolent engenho.

I also find it relevant to comment briefly on the plight of the freeman, who in a rigid two class system is still situated at the bottom, albeit he may be free. The free Creole Negroes were mostly employed in mechanical trades. It has been noted (Southey; 1822:787) moreover that,

The free people of color were an industrious and useful nart of the population: most of the maize, manioc and gulse, with which the towns are supplied was raised by them on small pieces of ground, which they rented from the great proprietors at a low rate.

These men were the first share-croppers or tenant farmers in Brazil. On the other hand, there were reportedly (Southey; 1822:676) fxeemen who chose to exploit their fellowmen: without the land and status of the sugar planter, these freeruen entered into illicit domination over slaves in the same manrer practiced on some engenhos. Evidence to this effect comes from an historical passage which reads (Southey; $1822: 676)$ :

Persons who had no lands to cultivate, bought slaves in order to live by their labor, and requiring from each a suim weekly, took no further care of them, but let them provide for their ow maintenance, and for their: weekly poll-tax as they could. If these wretches did not earn enough, as sometimes must have happened, or if they gambled away what they had acquired, they had recourse to robbery and murder; and though the magistrates punished such crimes severely (beirg perhass the only crime which were punished at all) they vere so mequent that it ias dingerous to pass the streets after nights had closed. It is asserted that women of rank and character trained up their female slaves for prostitution, for the sake of profit obtained by thus employing them. 
Southey, the British historian who compiled this information, concluaed that, "The practices of our ow Sugar Islands render credible this and every other atrocity connected with slavery." In sum, the position of the free worker in Brazil was a precarious cne situated between the large mass of slaves below and the poverful slave omers above. The free worker vas often a small merchant, an artisan, a military man or a would be professional, if he could obtain any education at all. Insight into the status of the free worker in the Northeast is, to sone degree, provided by a reference to the living conditions of the average free laborer in 1850 (Burns; 1966:235):

Dry meat, salted and many times spoiled--fish, flour without manior, bad food, a hard bed, an uncomfortable house, rasged clothing are the products which the poor use. Even these come in limited amounts in order not to exceed the budget. Under such circumstances, the family can only suffer.

Having attempted in the preceding pages to describe the social conditions which prevailed in Northeast Brazil in a formative cultural perjod between 1550 to 1850, I shall include one further statement which both clarifies and expands an understanding of social conditions which developed throughout this period and with which we still contend today. The following is an account of a social issue which appeared in the Recife newspaper, $\underline{0}$ Dírio de Pernambuco, on March 24, 1856; the article is entitled, "The Problem of Large Iandholdings in Pernambuco in the Mid-Nineteenth Century":

What fiuture has the contiruously growing population of the irterior? Wil the ne: additions devote themselves to agriculture? No. The more enlightened part will cone here to Recife to seek its forture, to solicit 
some ridiculous job. The rest will go to the towns and to other centers of population and there soend a miserable life because among us there is no industry that offers the free vorker security and regular pay.

This region which continues along the entire coast of our province and inland for ten, twelve or fifteen and eighteen leagues is divided into sugar plentations and properties whose dimensions vary from a quarter of a league square to two and tinree and even four and five leagues Equare.

Here, as the growing of sugar cane demands, a certain amount of land, which cannot be found everywhere, is devoted to tile cultivetion of cane. Other parts of the plantation are dedicated to the woods that are necessary for sugar production, the pastures for the care of the oxen, and the gardens for the planting of the manioc indispensible for the feeding of the slaves. But still a major part of the plantations possess vasi: extensions of uncultivated land that would be especially well suited for the small farmer and which, if cultivated, would be sufficient to furnish abundantly flour, com, beans, etc., to all the population of the province and of the neighboring grovinces with some produce left over for exportation.

The proprietors refuse to sell these lands or even to rent then. If you oim thirty to forty contos de reis you can buy a sugar plantation, but if you are a poor and want to rent or buy a small patch of land, you won't find any. This is what makes the unproductive population of the cities, increases regularly the number of solicitors of public employment, and raises daily the crimes against property; and the country becomes poorer day by day in consequence of the increase of the number of consumers wille the number of producers remains stationary or at best increases at a much slower rate.

But the landowners say that they are far from refusing the poor people the land they need to cultivate. They say that when these landless poor ask for it they give them at a small rental or at times gratuitously not only the land to plant but the wood to build homes. This does happen but only at the pleasure of the large landower. Anytime he wants to, for any caprice or because they refuse to vote for his candidates or for any reason, he can order them off the land and they hare no recourse. How can you ack those poople to plant whon they have no certainty of harvesting? What incentive exists to induce them to improve the land from which they can be evicted at any moment? 
In conozision,

Dn the land of the large property owners they do not enjoy ery public right because they do not have any treacon; for them the large landowners are the police, the courts, the administration in short, everything. Tre lot of these unhappy poople differs in nothing from the serfs of the Middle Ages.

This is Northeast Brazil's inheritance--a cultural tradition precedent of over three hundred years of domination by an elite aristocracy which derived all their wealth and power from land and sugar. With the advent of mechanization, in the later nineteenth century, as well as the abolition of slavery, social dilemmas of the kind described in 1856 becane further aggravated by the continual increase in number of an alienated, propertyless and miserable lower class whose subservient position had been fixed through centuries of tradition. In this two class syotem, the sugar planters and merchants, most of whon were direct descendants of Portuguese colonizers, came to measure their status in terms of property holdings, family ties, education and social and political connections. And since such goods and privileges were inheribed, it passed from generation to generation, tradibional fanily associations with both land and people became extromely imoprtant in assessing ones socinl position. The basis of this aribtocracy and their findy establiohed tradi-

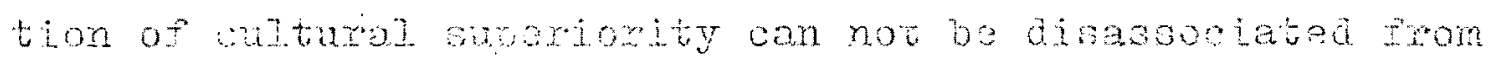

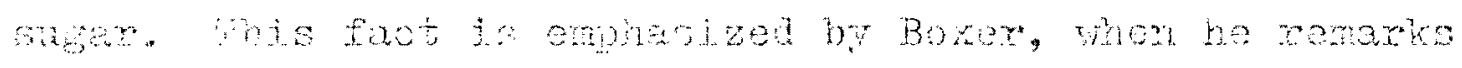
$(1965: 36):$

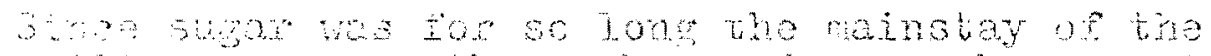

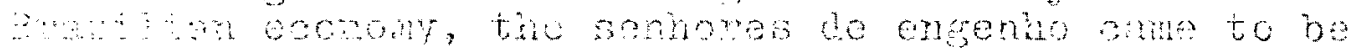


recognized as the rural aristocracy and were awarded corresponding privileges and immunities. Gubernatorial and royal decrees exempted their sugar mills, technical equipment and slaves from being seized or distrained for outstanding debts. Their creditors were only allowed to take a portion of the cane fround at harvest time. These privileges were late extended to the lavradores or copyholders who cultivated smaller fields and had their cane ground by the planters.

Hovever extencive the rights of the so called sugar nobility, their status likewise inferred obligations to society. Thus, it has been that the leadership in Brazil, politically, socially and economically has been assumed in great part by the agricultural elite; the elite in the Northeast. As Gilberto Freyre has succinctly said (1937:9-10):

Iuring the decisive period of the formation of Brazil, the history of Brazil was the history of sugar, and in Brazil, the history of sugar attained its major economic importance and human involvement in the Northeast. 


\section{- POST ABOIITION: THE RECENT PAST}

In the nineteenth century a number of social and political changes took place throughout the tropical regions in the Vestern hemisphere where cultural patterns based on the supremacy of sugar had been firmly established for at least two hundred years. For one, slavery was declared illegal and this constituted a major blow to the industry since it was dependent upon slave labor. Under British pressure, Brazil agreed to halt the importation of slaves in 1831. However, the Brazilian public was not then ready to accept such a move and increased numbers of blacks continued to arrive on the slave ships appropriately named, tumbeiros, or loating tombs. As the economic emphasis shifted from sugar to coffee (mid 19th century) European immigrants were attracted to Brazil and a middle class began to emerge resulting in increasing public support for the ending of slave traffic. An official ruling, the Quiroz Law of 1850, Jegislated against the further importation of slaves and gave provisions for the penalties involved in bringing and trading slaves into Brazil. In 1871, the Law of the Free Womb raied that all children born to slaves were hereafter free men. This law insured the eventual extinction of slavery and the public agitation for emancipation subsided 
until 1880 when the Brazilian antislavery society was established. The society initially lobbied for the SaraivaColegipe Law of 1885 which declared free all slaves over the age of sixty. Finally on May 13, 1888, the Golden Law emancipating all slaves, and firmly abolishing the institution of slavery vas enacted, to the chagrin of plantation owners who, as Burns reports (1966:278) were frustrated, disappointed and who furthermore, refused to accept it. This sequence of events, however, indicated how well focused the political strength of the sugar planters effectively delayed abolition for more than fifty years after the initial demands.

Brazilian slaves had been cranted limited civil rights unlike slaves in the United states. The rights included the right to trial by jury, the right to possess property and the right to purchase one's freedom. Furthermore, baptism in the Catholic church gave slaves recognition as human beings whose role in the community was legitimate albeit very low in status. In the United States, on the other hand, slaves had no acknowledged position in society, and henceforth, emancipation created a large group of heretofore unrecognized persons who now had to be incorporated into the social structure. In Brazil, the traditional colonial social structure included slaves in the two class system, and rorover, tho precodent of various contractual agreements between the slaves and masters e.g. working a small parcel of land one day a week for personal profit, facilitated 
the alleviation of social pressures created by emancipating thousands of slaves. In Brazil, the practice of contractual agreements was extended to include the many persons who did not wish to leave the land. As Hutchinson noted, in fact, (1957:8) many Brazilian laborers continue to work the small plots inherited from their slave ancestors and much of the land still belongs to the same families who operated the original plantations. Thus, the extension of a pattern which prevailed during the time of slavery served to accommodate the emancipated slaves into the socio-economic system which remained largely dependent upon the sugar industry-particularly in the rortheast.

In 1889 the Republic was declared. This event also challenged the position of the sugar aristocracy for they had based much of their social supremacy on their rights as nobility and their fidelity to the crown. When, therefore, the source of their aristocratic inheritance was severed from Brazil, they suffered from what might be referred to as a credibility gap; their economic dominance maintained their social and political controls, however.

Other major modifications were brought about by technological innovations in the realm of sugar refining. The increased competition on the world market stimulated the introduction of steam powered machinery which made possible the creation of the large central mill. The loss of slave labor was a catalyst in this technological transformation, which is commented upon by Hutchinson (1956:5): 
Thus, the "factory in the field" came to the sugarcane industry and set off a series of changes in the former sugar-cane way of life wich reached beyond the sugar plantations into regional economics, into the structure of the local communities and into the social class system. It implied more modern and far greater capital structure for the industry, different types of relations between employer and employee and the growth of a body of skilled workmen and office workers.

He also notes some of the further changes which have occurred in the sugar plantation organization:

Land owership has passed out of family hands and onto the hands of large scale corporations, the actual owmers of which are most often absentee. Administration is in the hands of corporate employees and specialists. The field hands and mill workers are employees of a large, impersonal corporation, basing their rights on labor laws and labor unions rather than on paternalism and traditional family obligations. The corporate, central mechanized mill, which is the center of a large corporate agricultural enterprise is larger than any of the old olantation types and far more efficient. Its operations are based on the cooperative efforts of agricultural, mechanical and chemicai specialists. Transportation and communication are better and factory tows of the new tyoe feel the pull of modern urban patterns more strongly than did the old plantation nuclei.

On the whole, the changes outlined above do not typify what has happened in the Northeast. This pattern more accurately characterizes the advances in regions such as Puerto Rico and the southern United States, where greater capital investments and more sophisticated technology were available much more than in Brazil.

Brazilian resources couldn't compete with the American capabilities. Moreover, the Northeast remained an isolated region in Brazil, itself, particularly when coffee became the major export product and left sugar in secondary position 
relative to the national economy. Both the geographic isolation and the waning economic importance of the Northeast's sugar production were prime factors in the economic and social stagnation which characterized this area. Patterns which pertained to the plantation system of the slave era continue to constitute the present social system despite new rhetoric; the master is now the employer and former slaves and their descendants are employees or share croppers. Relations between employer and employee remain essentially paternal on the part of the former nasters and the laborers are in some ways as dependent as the slaves were for food and housing. But, before discussing this point in detail, I would like to point out that the plight of the ex-slaves is a key factor in understanding the nature of the social. structure on the Northeast. Observations regarding the options available to the lower class freeman who has no family status, no education, no property, or other financial resources but who invariably must support a large family, are prime clues to the notion that the traditional social system, so strongly influenced by sugar and the master/slave syndrome continues to function in contemporary contexts. There are two main areas which help illustrate this phenomenon: 1) living and working conditions of the rural laborer and 2) conditions and situations available to the rural migrant.

\section{I focus on these two areas because they reflect several} of the salient aspects of the Northeast today. First of all, the fortheast remains agricultural; industrialization, so far 
has had little impact on the Northeast (Callier; 1966, Furtado; 1970). The plight of the rural agricultural population is one of the most serious problems of the Northeast for their perpetually precarious economic situation is severely aggravated by the frequent droughts which plague this region. Secondly, the migration of rural inhabitants to the cities, namely Recife, results in tremendous dilemmas of insuficient and inadequate housing and unemployment, to mention only two of the problems connected with the influx of migrants. The fact that so inuch of the urban population has a rural background makes this an important area for observing the kinds of social relationships that are important in integrating individuals into the urban social system. Firstly. I shall examine the situation of the rural laborer. In Pernambuco, 73.6 per cent of the mata is devoted to sugar cane. Ihis accounts for 80.7 per cent of the agricultural production of the region (Table I, Appendix). Note that mandioca is the second largest crop. Mandioca is the staple food for the lower class who can not afford fresh fruit ard vegetables and meats. Since they have never been accustomed to a diet which includes a balance of nutritious foods, even if such foods are available, they customarily prefer nardicca. I observed this preference when visiting the hones of small farmers living in the interior. In fact, one of the problems of raising a crop such as tomatoes, is marketing them in the interior; the lower class population does not customarily eat much frujt and vegetables. In a 
detailed strdy of the conditions of rural workers in the cane groving regions of Pernambuco, Congalves reports the Soliowing staristics $(1966: 117-170)$ :

Mable II shows that 0 all the persons over ten years of age, less than half (49.2 per cent) have a wage paying occupation. Practically ali the professions listed are connected with the cultivation and/or processing of sugar; many of the jobs are directiy related to sugax cane such as cane cutter 28.1 per cent; wight man 21.7 per cent; cane cleaner 6.3 per cent. All together they comprise more than 60 pex cent of the persons wino mork for wages froin whence one can deduce that the struature of the actively employed population is litile diversisied, and perhaps not much different from fifty or a hudred years ago.

Teble III shows that anong the 477 resideness surveyed, 85.1 per cent of the houses in the cane regions are prasented by the employer as a condition of employment. only 10.7 per cent of the houses are cmed by the workers and 2.5 per cent are rented. In other vords, 85.1 per cent of the nonsing bolongs to the sugar planter, a situation not unsiniIar to when the sugar planter orovided housing for his slaves. Teble IV indicates the epplication of salaries. This informition alone reveals a great deal about the living condtion of mot of the ponsons interriewed in this cane

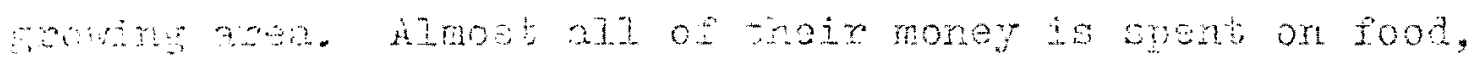

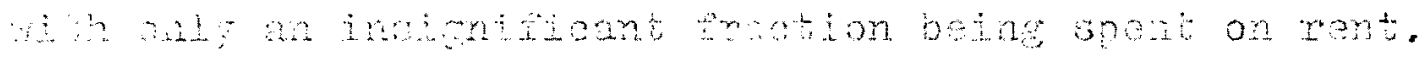

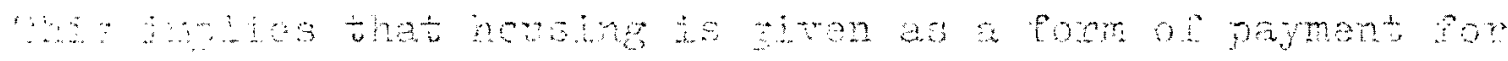


work. In almost all cases no money is spent on electricity or water, because neither of these facilities is available. In all, the study implies how little conditions have changed in the past century. As I mentioned, the existence of certain civil rights during the colonial period are important in understanding the contiruity of the social system which characterized the plantation system of old. Here, I am specifically referming to the unique aspect of IusoBrazilian slavery which allowed slaves to work for money on the side in order to buy tineir own freedom. The laws empowered a slave to demand his or her freedom whenever he or she could ofier to the omer the price which was originally paid for him or which he was considered to be fairly worth on the market. In conjunction with this right, it kas been noted (Southey; 1822:781) that slaves often contributed to their own support by maintaining small gardens. It was precisely this precedent which facilitated the transition of: slave/master to employee/employer, and this practice, largely accounts for the permanence with which so many Northeasterners regard their relationship to the land. Rural laborors becane, therefore, integrated into a social system which was structuraliy equivalent to the social organization of tire plantation system of 1750 . Thus, despite the technological innovations and the emancipation of the slaves, contemporary labor conditions indicate that the actual social structure has not been modified. As Hutchinson has aptly stated (1956:8) in Brazil, in contrast to other sugar growing regions in the 
Arericas, emphasis was on the improvement of milling techniques, the further refinement of sugar cane juices and the perfection of the finished product by the central mill. The agricultural methods, on the other hand, planting, cultivation, harvesting and transportation have not been significantly changed from colonial times. Moreover, Hutchinson adds, "With the retention of these older techniques has gone the retention, to a very great degree, of the old accompanying social system." The present social. system tends to follow the old traditional family oriented, slave holding complex. The pattern of face to face interpersonal relations developed during the centuries of eugar cane monoculture besed on slavery persists in a modified form. Although the relations between the workers and the ormer of these family plartations are now those of employer and employee, and not of owrer and slave, there is still a highly personal, intimate relationship based or mutual rights and obligations and a sense of noblesse oblige. Even the system of a number of plantations utilizing a central mill (the usina) perpetuates this kind of paternalizm, in that relationships between the mill and the individual cane growers are based on a reciprocal set of expectations and responsibilities. This is well illus.trated by the fact that most of the laborers on the plantations receive housing beriefits from the land owner and, whereas the laborese work the field of the plantation omer, they still maintain small garden plots for their own subsistence. 
In another study, Callier (1954) also discusses the fact that most of the small farmers reside on or work land that belongs to big land owners. Small land holders (ten hectares or less) represent 76.6 per cent of the total, and in Pernambuco, occupy only 9.4 per cent of the total agricultural area. In contrast, holdinss of 1,000 hectares or more represent 23 per cent of the total land owners, and 23 per cent of the state's agricultural land. To further translate from Callier's study (1964:178-82),

The system of large land holdings is maintained by the practice of tenant farming. The farmer receives a home and a piece of land on which he plants his field, with the help of his family. In exchange, he must vorle for the ormer several days a month, especially during the periods of planting and harvesting. For this "help" he receives a very low salary, or instead, he pays some rent or gives the owner part of his harvest.

On the modern usinas these options for subsistence have disappeared. Instead, one can distinguish only téchnicos (technicians) and operários especialzados (specialized laborers) who are better paid and housed with social security than the trabalhadores agricolas (field laborers) who have no specialization and who receive a very low salary and live in vilas operárias (worker's residences) which, for the most part, resemble slave huts.

In the sugar cane zones, the social structure reflects a culture based on a monocrop economy and slave labor. There is a social pyranid wich etill has the adrinistrators and the landowners on top. They substitute the traditional slave masters. The agricultural laborers, stationed at the bottom, 
represent the former slaves. Callier outlines the present social system as follows:

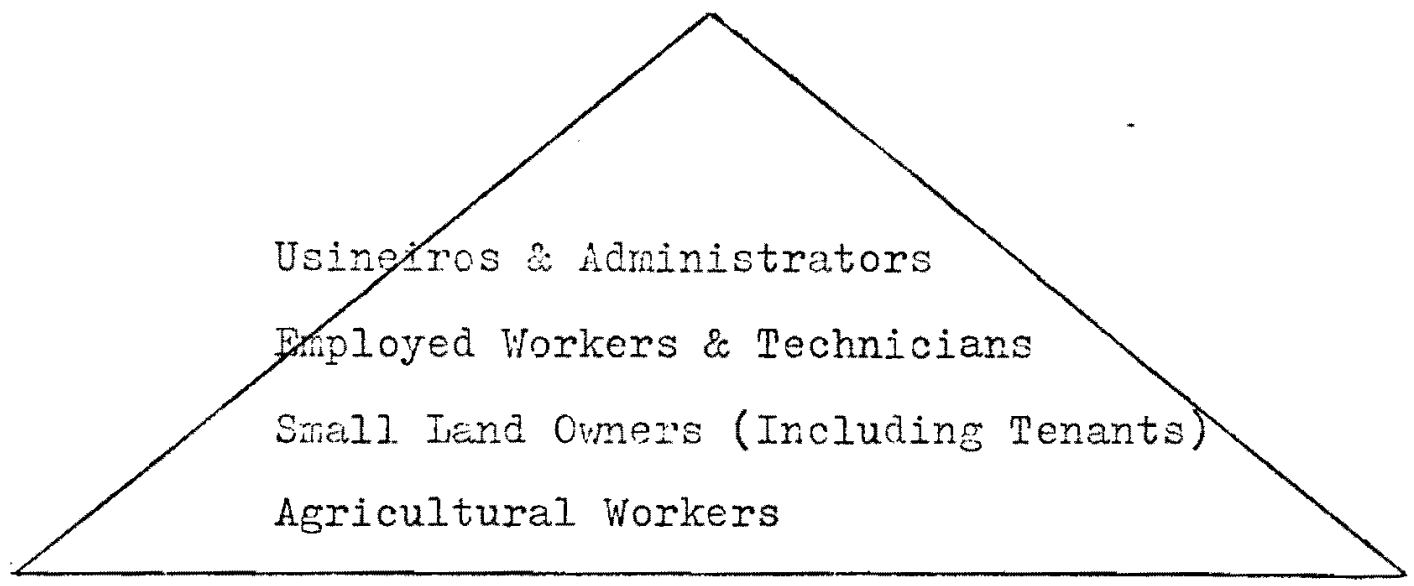

Since a great deal of the land is fractioned, it is not uncommon for a small land owmer to work parcels of land that are not contiguous. Most small property owmers barely maintain themselves, and their economic margjnality is aggravated by the harsh natural environment that often provides no vater for crops or stock. Moreover, there is constant pressure from the bigger land owners to allocate the better land to sugar production. As frequently occurs, many small land holders are finally obliged to renounce their independence and become salaried workers in order to secure enough incore to support their families. Since most of these persons are illiterate, they do not have access to the class of technicians and specialists. The only route of social mobility is to migrate to the city where they can seek a different occupation and bottex pay than they receive in the cane fields. Callier reponts $(1964: 9)$ that almost three fourths of the migrants arriving in Recife from the interior are former 
arricultural laborers from the cane regions. Charles Wagley (1954:3-22) has referred to this group as the "subculture of the fazenda" ( $f a r m$ ). He furthermore suggests that Brazilian society consists of the following distinguishable subcultures:

Rural

Cabocla--.-.----Rural Independents

Fazenda-..-----Salaried Workers \& Share Croppers Metronolitan

Lower Class

Upper Class

The rural independents usually live in jsolated areas of the interior. They are small farmers who use slash and burm techniques of agriculture, fisherman and men who ow small herds of cattle. At the other end of the spectrum, the upper class can be characterized by the large land holders descended from the colonial plantation owners. Large old familjes and families with business interests as well as the higher ranking military families and the bureaucratic executives represent the upper class, also. The subculture of the rural laborer, wich is of main interest here, is characterized by a subordinate/superordinate relationship between land owner and worker. On the large estates and in the communities dominated by these estates, the relisious, political enc econonic leadership is concentrated in the hards of the land omers. The workers, per se, remain dependent upon their getrons for food and housing and instructions on how 
to vote, etc., and maintain relations through personal ties rather than official negotiation.

What is the nature of the urban environment the rural migrant encounters in Recife? First of all, the urban environment is nore heterogenous than the rural, e.g., in Recife there are a number of lower class neighborhoods which each have a unique identity. The homes in these neighborhoods are not large or elaborate. Their yards are not lawn, but rather dirt and in many cases the houses are not separated by walls and fences as in the more expensive districts. Homes do not generally have running water or electricity, although there are street lights and centrally located water faucets. The inhabitants of these neighborhoods are generally employed as domestic servants or wage laborers of some sort. Because of the open nature of the housing arrangements, there are many interpersonal ties within the neighborhoods, but each district is, in itself, a closed community in the sense that an outsider is easily recognized and there is a sense of comraderie among those who live in the same district. Neighborhood solidarity is often reinforced by the competition between local soccer teams since the Brazilians are such avid fans. Personal contacts are very important in these neishborhoods, as a means of security in terms of reciproce] favors as well as in tems of providing initial acceptance and guidance for the newcomer arriving from the interiox. Such relationships are generally with relatives at first, and relationships developed between neighbors becore smportant after one becomes a member of a given 
neighborhood. Kinship and pseudo kinship alliances provide emotional and financial assistance to the rural migrant and alleviate anxiety caused by the unfamiliarity of the urban environment. In the city, one must contend with more impersonal relationships in ones daily activities, because it is not possible to know everyone, as in a small community. It is in this sense that the neighbolhood resembles a small rural commity; it provides the emotional environment which counteracts the impersonal nature of a big city. The personal ties one has aid in finding a job and knowing other people and in a general sense facilitate the assimilation of the rural citizen to the urban culture. Influence and behavioral models from neighbors and relatives serve as a means o $\hat{I}$ "coaching" an individual in coping with the new situations and in developing vehavioral patterns characteristic of metropolitan living--these patterns range from learning how to cross the street to knowing to take the bus across town.

Family ties have traditionally been important in Brazil. Socially, economically and politically, the extended family has been a primary unit in Portuguese history as well as in the development of Brazil (Williams; 1969:52). Compadrade has been a way of extending familial bonds to non-relatives as a reans of securing protection and guidance of a child. The functions of the family is the most obvious expression of the fact that in Brazil, emphasis is put on personal, sympathetic or primary rather than on impersonal, 
categoricel on ceoondary relationships. One feels that human understandins and sympathy can be achieved only through the more intimate forms of contact with people. Fven today, people prefer personal visits to telephone conversations, as a means of conducting business. Thus, high omotional value is attributed to blood relationships, godparenthood and friendship. These three type of social relations are I frely to encroach upon any other form of institutioralized relationship, whatever be its degree of remoteness of social distance (Williams; 1969:58).

The importance of the family is reflected moreover in the extension of familiar attitudes to those not actually mombers of the fanily but in close contact with the family. An example of the paternalism characteristic of Brazilian culture is, of course, the relationship between the master and his slaves. He cared for them and their families in a way that demonstrated his paternal concern. They, in turn, were loyal to the family and the family name, in much the same fashion a son or daughter. The paternalistic position of the plantation owner towards the slaves is paralleled by the paternalistic attitude exhibited by the upper class towards the lower class. Perhaps one of the best contemporary examples of this tendency is the nature of the relaticnship between upper class patrons and their domestic servants. During wy stoys in Brazil, both es an oxchange student and on a Fuloright, I had ample opportunity to observe the interactions of waids, cooks, gardeners and chauffeurs and their 
respective erployers, thus, the following comments are based on personal experience in a variety of situations.

The stance of servitude on the part of the servants is exhibited through loyalty to the house, and patron family. A good servant is in turn, given housing--in servants quarters-wilich are usually built in the back of the house or apartment or in the backyard. Even the most modest apartmext vill have a sinall ( $7 \times 4$ feet) room and adjoining bathroom usually located off the kitchen for the purpose of housinf a maid. Servarts also generally receive clothing for most patrons at least provide clothes for the maid or cook to wear while vorking and many times older clothing from the "masters" family is given to the servants for their femilies and themselves. Servants, generally receive all their meals at their employers home and I have observed numerous occasions that servants take left over food home to feed their children. Besides these remunerations servants also receive a small wage--probably about 30 a month (100 NCR in 1968-69). If a servant doesn't live in, the employer generally provides extra money for the bus trip to and from work.

Beyond conditions of employment a servant who stays vith a family for a number oi years is frequently regarded as somewhat of an extra famiiial member. Illness of the veriant on a momber of his fanily is jnow and ofton attended to by the mistress of the house. Joyful events, such as births, and marriages are acknowledged by patrons with gifts 
and time off. It is not common for a well-liked and favored servant to ask the patron to be godfather or godmother of a child. The advantage to lower class persons in forming an alliance with an upper class patron through compadraoco is in assuring social security for their child. It is a very personal relationsinip which not only reinforces the obligations of the servant to the employer but which also provides for the paternal guidarice of the young, lower class persons by the dominating aristocracy.

Another illustration of extending family rights to servants is the practice of including them at Christmas and upon all other important family occasions. Servants customarily receive an extra month's pay at Christmas as well as regular Christmas presents like clothing, or household equipment. Not only do patrons give presents to their servants but often to their servants children as well.

There are, of course, many cases wherein the maid, cook, gardener or driver is not considered a "good" servant: perhars they are not dependable, are constantly ill, are too slow to learn, or they steal from the patron. In such cases, no sonds of familiarity ever form or reach the point of being reinforced in the afore mentioned ways. By contrast, however, families who have loyal "responsible" servants proudly introcuce thom to visitors and take care of then well--by providing the extra beneits like clothing and housing. Such a relationship also implies mutual respect whereby patrons do not generally verbally abuse their servants or overwork 
them. Host servants get one day off a week which is usually Sunday.

Families with children are particularly familiar with servants since they entrust their children to them in so many instances (i.e. to take children to the beach for a walk, or to the cinema, etc.). The familiarity, however, usually results in the servants knowing as much or more about tho children and how to handle them as the parents. Difficulty arises when children try to pull rank on a maid by doing something their parents wouldn't allow. Sometimes, the servant has a strong personality and can control the child although in other cases, I have seen children bluntly remird servants of their superior status by proceeding to do as they please. Watching children interact with servants sheds valuable insight on upper class values--for it is quite apparent that upper class Brazilian children conceive of themselves as young aristocrats and much of their training in this role is acquired through interaction with servants. It should be quite clear by now that the many aspects of the domestic servant/patron relationship represents a cultural parallel to the traditional master/slave pattern of interaction and reciprocal rights and obligations. Thus, among persons who have never been in a cane field and who disdain the concept of slavery one can observe many of the same attitudes and practices (of paternalicm and subservience) that characterized the traditional man/patron syndrome. 


\section{CHAFTER IV}

\section{CASE STUDIES}

I have examined the conditions of the rural worker in the Northeast and discussed the conditions regarding domestic help as illustrations of cultural areas wherein practices and values obviously reflect the past. These are relatively overt examples of cultural continuity compared to the more subtle manifestations of the man/patron pattern in contemporary business contexts. In most present day situations, the pattern is obscured by the superimposition of social practices and positiors and titles (e.g., President, Vice President, Executive Fanager, Administrative Assistant) accompanying the bureaucratic administration of economic development.

The intermeshing of such new cultural features with the o]der persisting aspects of culture have been referred to as "interlociring networks" by Anthony Leeds (1964:1333). The man/patron relationship provides a good example of this phenomenon in Northeast Brazil. The relationship, per se, represents a traditional social pattern which was a key to the nature of interpersonal interaction in a social system which characterized the Northeast for several hundred years. turthermore, in examining the relationship in contemporary exvression, the man/patron phenomenon does represent an "interlocking retwork" in the sense that it serves to link 
traditional values with cultural elements recently borrowed or evolved. The point to be made in using the man/patron illustration is that there is a persistence of the values by which people establish interpersonal relationships and these values, therefore, continue to shape the nature of the social system despite a new look created by industrialization, urbanization and the dissipation of the sugar plantation syatem.

The following data provide samples of situations wherein cultural innovations are juxtaposed with traditional institutions. In describing the cases, I have attempted to note the presence of values related to the man/patron syndrone which pertain to patterns of social interaction. The first case deals with the sugar business and clearly reflects the conservative nature which has traditionally characterized the sugar aristocracy. The second case reveals persisting social patterns as they underlie a facade of new organization. The remaining data presented as case three, illustrate other instances where the man/patron relationship is variously manifested in different contexts.

\section{CASE STUDY \#1}

The JIRON program was a joint Braziliar/U.S. attempt to accomplish several related goals all of which are alligned to problens involving lend reform in the Northeast. JERON specifically ained at the sugar industry and the lands and resources connected with sugar production. The program was 
in existence approximately three years, during which time it was administered by the director of the USAID program in Recife. This man was also the counsul for the U.S. diplomatic mission in this region, so the joint weight of his position theoretically lent considerable credibility and facility to program operations.

Briefly, JERON was conceived to promote 1) more efficient land use, 2) more crop diversity and 3) redistribution of land. Methods involved were ultimately designed to assure the giving of land, both good and bad, to the govermment who would in turn, reallocate it to small farmers or cooperatives, and offer to the "donor," as, it were, government loans at low interest; such loans applied to improvement of the land and other technologicel assistance which vold supposedly incrcase the total output of a given usina's sugar crop. The recipients of the land would also have access to technological assistance including economic advising as well as use of technical equipment. It is understood that the U.S. has encouraged the Brazilian government to pursue the redistribution of land in the Northeast as a means of combating the gross inequities in the social and economic systems. However, on the other hand, the sugar industry remains important not only to the regional economy and the national economy but the U.S. as well, since America imports a good deal of annual Brazilian crop.

The U.S. has encouraged the Brazilians to attempt these agricultural reforms, while simultaneously offering a premium 
price for sigar on the world market. This would appear to be a contradictory policy from the point of view of the usina owners in Brazil, for decreasing their amount of land would seemingly effect their total output. Technical improvements and other investments might compensate for land loss but, strictly speaking, participation in the JEROH program appears to be a large risk for the usina owner--given the unpredictable conditions of the world sugar market as well as ecological variables which frequently elude human control.

This being the case, what incentives exist for involving usinas in the program? What, in other words, is the position of the director of JERON in getting participants for the progran?

In theory, JERON is a procrom well desimned to accomplish goals of land reform. In actuality, there are conflicting interests which largely preclude any amount of enthusiasm for the program on the part of the Brazilians who om usinas. Despite political pressures to participate in the program, the fact remains that the large usina owmers, nost o: whom are not in residence on the usinas, do not see it in their personal interest to give up any land. Unless in dire need of financial assistance, the JERON program does not offer the usina owner anything to which he does not formally have access. Being of position and wealth, any usine omer can secure lown to improve technolosy--but given the labor supply, there is no great incentive to technologica.1 ly renovate the usina, and thereby mechanize 
the entire operation since this would eliminate the jobs of men and women whose only work is to the cane fields. The implications are already clear--the question of land redistribution is related to technological development which in turn is not only a matter of financial resources but also a social dilema involving the employment and welfare of countless persons. Given the traditional sense of obligation sugar planters have felt towards their laborers, it is understandable that such matters would enter into any decision involving considerable reorganization of the techniques and resources. If nothing else, this argument would effectively explain their reluctance to relinquish their lands even if they vere nerely concerned with profits-for the U.S. premium paid on the world market of approximately 60 to 80 dollars a ton, appears to sufficiently encourage usina owners to retain every bit of their property. A specific example is the Cavalcanti family of Recife who represented one of the few usinas to participate in the JERON program. The Cavalcantis ow one oî the oldest homes on the elite Avenida Boa Viagem in Recife, and they have been traditionally involved in the political and social leadership of Pernambuco since the Cavalcenti family has been in sugar for centuries. Involvement in the JERON program caused great ambivalence for lirs. Cavalcanti who was very concerned that her son would not possess the family lands that had supported the family for Eenerations. She reportedly remarked, to an informant, "What will my son do if he can' $\tau$ make a living growing sugar?" 
The problem of inflation, 23 per cent in 1970, caused sufficient difficulty for sugar producers, anyway, let alone the possibility of reduced land resources. Even with the same amount of land it is difficult to maintain the same income year aIter year. The Cavalcantis have approximately 250 persons on their usina, and they are rot paid in wages, but in rent, food and clothing. In other words, their employment on the usina is their life--the usina is their world, and Mrs. Cavalcanti expressed both worry about her responsibility to these people and the possible results of any drastic changes in the usina system as pertaining to her own income.

\section{CASE STUDY \#2}

The Conperative nrogram in Pernambuco provides an example of how traditional patterns of social interaction and traditional. values continue to influence behavior of persons involved in movements and organizations introduced from the outside. In other words, the co-ops illustrate how traditional patterns of interaction underlie, and in part, undermine, the operation of programs that have recentiy been set up under the direction of outside agencies.

The Cooperative program began in $1962-63$ as a joint effort of Brazilian and U.S. agencies. Throughout the 1960's the peace Corps was directly involved in the establishment and adrinistration of co-ops, in Pornambuco, althoush in very case, the co-op was founded and supported by local interests. Nost of the small town in the interior have 
co-ops which service the small farmer with general merchandise, and, sometimes, technical or financial assistance. I became most familiar with such a cooperative in Afogados, a town located about 200 miles from Recife, a distance which takes ten hours by bus. The case of the Afogados co-op illustrates clearly that the traditional man/patron relationship influences the business managenent of the co-op despito the existence of a formal organization imported, as it were, along with the concept of the cooperative. It is important to note, at this point, that there is no precedent in the traditional culture for the idea of a cooperative. The entire concept of contributing to the general welfare is not an aspect of the culture of the Northeast, particularly the mral Northeast. In the whole region, the people have forever been victims of drought, famine and disease. As such, the Northeast is an extremely impoverished region, and the ability to physically survive the hardships have largely depended upon familial support as well as ingenuity and stamina. In brief, the subsistence level in the Northeast is incredibly low for most of the population. Gilberto Freyre has mentioned in fact, that living conditions for the majority of persons is worse than in times of slavery, when at least the master would provide the essentials such as shelter and food. Surplus is a relatively unknown commodity and tis concept of sharing with persons outside the family is rarely expressed. People strive for themsejves so much that little time or effort can be afforded in terms of 
helping others. This foct can be documented with several illustrations: 1) There is one field well in Afogados and it belongs to zé Vera. He is a relatively prosperous farmer, and the water is for his use alone. In contrast to zé Vera's mechanized water supply and irrigation syster, neighboring farmers spend eight to ten hours a day making sure there is suficicient water for their plants and animals. In this sense, there is no cooperation or division of personal resources. 2) A second example involves the Church, which one might think would promote community cooperation, but there is no institutionalized effort as such. On the contrary, when Afogados suffered from a serious famine in the fifties, the Church, in Afogados, under the present Bishop, gathered as Hucin food as pussible arrä distrivuled $i t$ in the face of a starving mob which had organized to storm the city and steal what they could. The Church, in this action, was not encouraging the people to cooperate among themselves. Rather, the Bishop assumed the responsibility of saving the people by using the power of his position and the Church's resources. His action was not unlike that of the master who dominates and protects the slave, and the slave, in turn, responds with gratitude and service.

The Bishop also plays an important role in the cooperative movement in Afogados, and it is relevant to mention some of the Bishop's activities in attempting to describe the nature of his position in the program. Historically, the Bishop has been involved with political programs in education. 
Prior to the Revolution of 1964, he was associated with MEB (Movimento de Educacão Básica) since this program operated in the interior primarily through the local radio stations. The Bishop happens to own the radio station in Afogados, which is the only station within a radius of seventy miles. MEB was virtually destroyed in the Revolution and, consequently, SORPE, an agency of the Catholic Church, became the leader in community education. The Bishop was very involved in this program through both his interests in the Church and the radio station. Moreover, he simultaneously supported the cooperative movement as well as the sindicato (union) movement. He was reportedly much more active in the sindicato movement, however. Nevertheless, his participation and patronization was actively sought by both organizations since the Bishop lent considerable prestige with his attention and connections. With regard to the co-op in Afogados, the Bishop exerted his influence through Iuiz Marquez, the President of the co-op. It is this relationship which most specifically illustrates the man/patron phenomenon. The relationship reveals that the major influence in the decision making comes from the Bishop, for according to the traditional values, he holds the superior position. His position is dominart vis a vis Iuiz Marquez, despite Iuiz Marquez' title of President, because, in terms of property, family and connections the Bishop far outranks, so to speak, any of the co-op officials. The Bishop comes from Recife, where he was educated in private schools. In Afogados, he not only owned the 
radio station, but also the sole jeep. He reportedly had an attractive mistress, and it was also common knowledge that the Bishop had close associations with politicians and journalists. Iuiz Marquez, on the other hand, was a poor farmer who struggled to support his ten children. His position as president of the co-op was attributed to his relationship with the Bishop, for Luiz was an avid participant in Church arfairs. Although Luiz Marquez personally takes his role as president quite seriously (he introduces himself as $\underline{\text { presidente), }}$, it was apparent that this position did not have much status in the community. Zé vera, for example, disdained Iuiz Narquez for his role as the figure head president of the co-op. Noreover, zé Vera refused to be e memher of the co-op for ressons relating to his dislike of the Bishoo.

In sun, this case emphasizes the continual influence of values which pertain to the traditional system of measuring a person in terms of property and family, etc., instead of responding to an individual in terms of position, responsibility or title. The social organization of bureaucracies aictates that persons be recognized in terms of their qualifications and dutjes. However, traditional values in the Northeast often disregard abilities and performance in lieu of such things as wealth, posseasions and associations, This is precisoly the case with the comop, where the president is ineffectual, in terins of his position becanse he does not have family name or importance, wealth, education or alliances 
with such people. He holds his position because of his friendship with the Bishop, who uses luiz Marquez's subordination to influence the co-ops policies. The Bishop has this power by virtue of his social status and wealth. It is a classic example of the man/patron relationship as it operates in a way wich subverts the intended nature of the cO-OP.

\section{CASE STUDY \#3}

A) Joel Souto Maior is not wealthy, nor does his family have political or social influences. However, Joel received a scholarship from SUDENE to do graduate study at an American university in the area of hydro-geology. There is a great need for Joel's knowledge and ability in the Northeast, for the water resources are oniy recently developed. For industrialization and improved agriculture, it is imperative to channel the limited supply efficiently and effectively. Therefore, Joel's study in the U.S. justly obligated him to return to the Northeast (Recife) to contribute to the efforts of SUDENE. When he returned, however, he was not given the opporturity to utilize his knowledge. To his dismay, he was assigned to work in the library, and only sent to the ifield very infrequently, and then, to remote areas. Apparently, Joel's education was not appreciated but was regarded as a threat. He reported that this was not just the case with older personnel whom one might expect to be threatened by youth, but he also posed a 
threat to younger men who possessea all the associated attributes which traditionally and theoretically accompany a higher education. Since Joel had no family prestige or wealth or political connections, it was as if the legitimacy of his knowledge and experience was denied. He spoke of going to Rio or São Paulo where he felt it was much easier to be accepted on one's owm achievements. He was quite ambivalent, however, for he felt comitted to the efforts to develop the Northeast and he resented the fact that in the Northeast people still pay homage to such things as family name, etc., or discriminate for lack thereof.

B) A phenomenon which can be documented many times over is the use of Americans as patron by enterprising Branjijans who wish to achieve some vertical mobility in the social system. It is interesting, of course, that the Americans who run the embassy and programs such as AID and Food for Peace, etc., do not, for the most part, come from the upper echelons of American society. They are generally "average" citizens whose jobs overseas afford them many luxuries they would not otherwise have in the states. At their overseas posts, many Americans have a life style, in terms of material wealth and social activities, similar to that of the wealthiest local residents. And, not withstanding the nouveau riche, the local elite commonly have had oreat vealth and prestige for genorations. For numerous poljtical reasons, most of which are obvious, Americans are readily accepted as members of the local upper class. They 
easily gain entrance into restricted social clubs and are often included in select social activities. In short, without regard for family name and background, the Americans are ipso facto members of the upper class and thereby obtain immediate and uncontested dominance over the rest of the society mercly because they look wealthy and have a significant political presence. Thus, Americans afford great opportunity for servants and Brazilian friends to associate with the patron class of society. Furthermore, Americans, who are generally unaware of the Brazilian values, more readily accept alliances with Brazilians who have no background, as it were.

A good example is the man who worked at the American Consulate ir Recife as a driver and photographer. Hêlio had a high school education and no political or social contacts, since his family has little noney. He, however, made contacts through the Consulate with journalists whom he would otherwise not have met. He began a business of taking wedding pictures on days he was not on duty at the consulate. Only by constantly saying he worked with the American Consulate would other Brazilians hire him for jobs. It was as if his association with the Americans lent him the prestige necessary for people to want his services. With the money he earned from photography, he is building a small shop where he will sell electrical equipment. In essence, Hêlio's contacts with the Consulate gave him a superior position, and relative to his peers, his accumulated wealth 
and social connections afforded him great advantage. Another such example is that of an artist in the Northeast. It will suffice to say that his work was unnoticed and not at all valuable until some Americans bought some of his work and displayed it in their living room. Although this artist has lived and worked in the same place for years, his reputations became tremendous shortly after the Americans discovered him. C) Cases of persons in positions of importance, who do not possess any qualifications for the job, present another expression of the man/patron pattern. The selection of personnel by virtue of their name and relationships rather than their experience or ability exemplifies the influence of values which derive from the time when one man could simultanoously play ten roles since the most important factor in assuming the position was the individual's personal prestige. In the following case it is clear that such criteria do not contribute to sound leadership.

Cesar is an economics student at the Catholic University in Recife. During the evenings he works for a local newspaper. His family has little political influence or wealth, but, in 1968, Cesar married a girl from a large and important family in the Northeast. It is quite apparent in observing the collier family interact, that one is first treated as a family member and seconaly as a professional person. The Colliers have inportant nilitary contacts, and throuch these, Iuci's father vas appointed the Minister of Transportation in Pernambuco. This is a very strategic position, finan- 
cially and politically, for Brazil is presently in the process of trying to link the Northeast with the southern part of the country in terms of transportation and communications. Upon his appointment, Sr. Collier made Cesar the director of the bus terminal in Recife. Buses are the primary means of transportation in the Hortheast, and being the biggest terminal in the region makes the Recife terminal extreneiy important to the economy of the Northeast. Cesar knows nothing about transportation systems and joins the unknowledgeable ranks of his two brother-in-laws who were also given appointments in the operation.

This variety of examples attempts to provide some concept of the fact that traditional values persist at many levels of society in the Northeast. It is indeed difficult to recognize some of the areas in which aspects of the man/ patron relationship manifest themselves. It is nevertheless evident, trat in each case, the persistence of traditional values contributes to the status quo of the social system. 


\section{CHAPTER V}

\section{CLOSING COMMENTS}

The aim of this study was to examine the nature of a persisting social pattern in Northeast Brazil--the man/ patron relationship. The historical overview reveals that this relationship was an essential feature of an entire social system aligned with the intensive production of sugar during the eighteenth and nineteenth centuries. Also, certain facts and observations regarding the present conditions of rural workers and domestic servants indicate that in these areas in particular there is obvious continuj.ty of cultural practices which were deeply embedded in the sugar plantation system. Furthermore, data presented in the case studies offers some indication of the persisting influence traditional values, as exemplified by the man/patron syndrome, continue to have on the nature of the social structure in the Northeast. Although in some instances, the manifestation of the man/patron relationship is obscured by cortcmporary social forms and labels, this study indicates that the criteria by which individuals establish and conduct relationships represent the continuity of values which distinctiy characterized the master/slave syndrome.

Celso Furtado, at one time head of the Agency for Developrent of the Hortheast (SUDENE), is a prominent 
Brazilian economist who has recognized that if traditional values continue to dominate key areas of the culture, they may, as such, contradict and, in a sense, defy, the institution of newer ideas and practices. He implores the need to recognize this matter in dealing with the economic and social dilemnas facing Brazil as a whole, and in this respect, he states, (1970:108-9),

There exists an inconsistency between the interests of those groups that control the process of capital formation and the interests of the community as a. whole. The core of the problem is not, however, in the behavior of the agents who make decisions in the economic field, which may be guided by strict criteria of rationality. Rather, the core of the problem resides in the structural relations that determine the field within which the relevant decisions are nade. This beings so, we have to ask if a policy capable of stopping the long term tendency towards stagnation will not have to assune a form of conscious and deliberate action to create structural melations and induce patterns of behavior which are capable of begetting social processes which will necessarily result in economic development.

Conceived as a strategy for modifying a social and economic structure, the policy of development can only exist in a society that has become actively conscious of its problems.

I agree with Furtado's statement of the problem and submit that data in this study as evidence to this effect. The very fact that the man/patron relationship still functions as a prevalent, albeit obscured, social pattern, indicates the preservation of the status quo despite the efforts of programs which have attempted to altercate the situation. If modification of the two class syatem, wheroin vortical mobility is improbably, is the desired goal, this will not cone about solely from economic development and investment 
of dollars. A change in attitude must occur, as Furtado has implied, whereby people are judged on personal merit rather than inherited characteristics, and competition and free enterprise are not impeded by traditional patterns of exchange and reciprocity. No matter how many schools and jobs exist, there is no social equity in a society in which people interact according to ascribed roles. The persistence of the man/patron pattern indicates that such is the case in the Northeast--and until such traditicnal values and social patterns cease to be reinforced, economic and social development will be thwarted.

Moreover, these initial observations regarding domestic servants, first prompted me to suspect that certain social patterns in contemporary society nerhaps directly reflected the traditional social structure associated with the plantation system. Interestingly enough, therefore, although the master/slave system had long since been abolished, economically as well. as socially, there appeared to be obvious parallels persisting in present day relationships--the nature of the domestic servant/dono relationship was the first of these parallels I noticed. It led me to look for further data representative of other possible manifestations of the master/slave syndrome in contemporary society. The case studies, therefore, represent several areas in which further research would be valuable in terms of better understanding the persistence of the heretofore dominant master/slave pattern. The case studies are in no way conclusive documents, 
but rather valid indications that a traditional social pattern is apparently the basis of given social interaction and relationships in diverse areas of today's society. 


\section{BIBLIOGRAPHY}

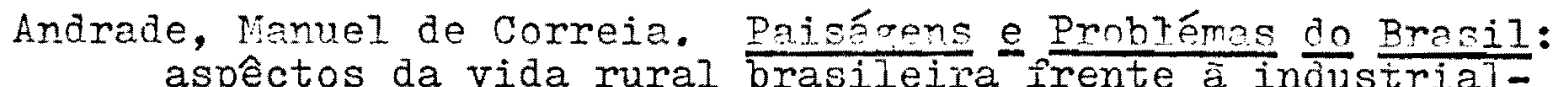
izaçăo e ao crescimento econômico, Editôra Brasiliense, 1968.

Antonil, Andrea. Cultura e Opulência do Brasil, São Paulo, 1923.

Barth, Fredrik. "On the Study of Social Change," American Anthropologist, Vol. 69, 1967.

Barth, Fredrik, "Hodels of Social Organization," Royal Anthropological Institute of Great Britain and Ireland, occasional paper, No. 23.

Boxer, C. R, The Golden Are of Brazil $\frac{1695}{1962}-1750$, Berkeley:

Burns, Bradford. A Documentary History of Brazil, New York: Alfred A. Knopf, 1966.

Braithwaite, Iloyd. "Social Stratification and Cultural Pluralism," Annals New York Academic of Sciences.

Callier, Colette. "A Migrant de origem mural no Recife," Boletim do Instituto Joaquim Nabuco de Pesquisas Sociais, No. 13 and 14, Recife, 1964-65, Ministêrio de educagão e cultura.

Castro, Josué de. Death in the Mortheast, Editôra Brasiliense São Paulo, 1966.

Castro, Josué de. Documentârio do Nordêste, Editôra Brasiliense Săo Faulo, 1905.

Freyre, Gilberto. Nordêste; aspectos da influência da cana sôbre a vida e a paisagem do Nordêste do Brasil, Livraria José OIympio, la ediçăo, 1937.

Freyre, Gilberto. INew Worla in the Tropics, New York: Alfred A. Knopi, T959.

Freyre, Gilberto. Masters and Slaves; A Study in the Development of Brazilian Civilization, New York: Alfred A. Knovf, 1956, original copyright, 1946.

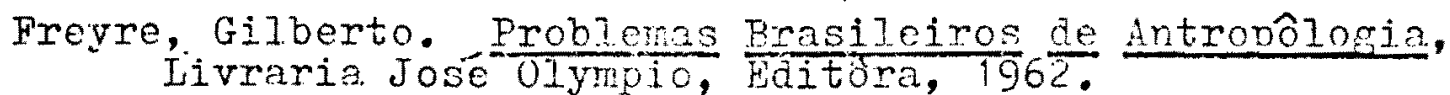


Furtado, Celso. Obrtacles to Develonmont in Iatin Amorica,
Doubleday,

Gonçalves, Fernando Antonio. "Condigões de vida do trabalhador mural da zona da mata do estado de Pernambuco 1964," na Boletim do Instituto Joaquim Nabuco, Recife, 1966, No. 15, Ministêrio de educaçăo e cultura.

Hanke, Jouis ed. History of Latin American Civilization, Vol. 1, the Colonial Experience, Wethen 7 Co, Ltd., London, 1969.

Harris, M. and Wagley, C. "A Typology of Latin American Subcultures," in Contemporary Cultures and Societies of Latin America, heath, eu. 1903 ranom House, pp. 42-67.

Hollanda, Sergio Buarque de. Raízes do Brasil, Rio de Janeiro, 1936.

James, Preston. Latin America, Odyssey Press, New York, 1942, "The Northeast," pp. 377-396.

Leecis, Anthony. "Brazilian Careers and Social Structure: An Evolutionary Model and Case History," American Anthropologist, Vol. $66,1964$.

Ieeds, Anthony. "Some Problems in the Analysis of Class and the Social Order," Social Stmucture, Stratification and Nobility, A. Leeds, ed., 1967, Pan American Union, Wash.

Leeds, Anthony, ed. Social Stmucture, Stratification, and Mobility, Pan American Jnion, Washington, D.C., 1967.

Ieeds, Anthony. Economic Cycles in Brazil: the persistence of a total cultural pattern: cacao and other cases, Ph.D. Ihesis, 1957, Columbia University.

Mintz, Sidney. "Cañamelar: The subculture of a rural sugar plantation proletariate," The people of Puerto Rico, Steward ed., 1956, University of IIIinois tress.

Southey, Robert. History of Brazil, Part II \& III, Burt Franklin, New York, 1822/1970.

Steward, Julian, ed. The People of Puerto Rico, Urbana: University of Iiiñois, T95.

Stevard, Julias. "Analysis of Complex Contemporary Societies and Culture Patterns of Puerto Rico," Contemporary Cultures of Iatjn America, Heath \& Adams, eds., Hew York: Ranaom House, 1905, pp. 30-41. 
Warley, Charles, ed. Rane arl clas in Rural Brazil, Unesco, New York: Columbia university Fress, 1952.

Wanderley, J. Hítôria de um ergerho do Recôncavo, 1552-1944, Rio de Janeiro, 1946.

Williams, Emilio. "Portuguese Culture in Brazil," Hanke Vol. 1 , Methen 7 Co. Ltd., London, 1969 . 
APPENDIX 
TABLE I

PRINCIPAI CROPS OF THE MATA--1964

\begin{tabular}{lcr} 
Type of Crop & Area in Hectars & $\begin{array}{c}\text { Value of Production } \\
\text { (Cr. } \$ 1,000)\end{array}$ \\
\hline Pineapple & 456 & 146.458 \\
Agave & 242,7 & 84.903 \\
Cotton & 4.211 & 290.263 \\
Rice & 142 & 5.589 \\
Banana & $5.178,9$ & 2.720 .341 \\
Sweet Potato & 2.549 & 549.590 \\
Coffee & $9.420,3$ & 449.825 \\
Sugar & 209.515 & 52.691 .057 \\
Coconut & $8.750,4$ & 1.954 .879 \\
Lima Bean & 1.071 & 56.546 \\
Black Bean & 4.479 & 364.510 \\
Tobacco & 141 & 7.511 \\
Orange & 840,6 & 728.520 \\
Castor oil Plant & 196 & 4.410 \\
Manioc & 27.733 & 4.454 .964 \\
Corn & 9.454 & 474.042 \\
Tomato & 181 & 267.425 \\
Grape & $284.485,7$ & 15.212 \\
TonAt & & 65.275 .445 \\
\hline Tarade; & & \\
\hline
\end{tabular}

(indrade; 1966:69) 
PABIE II

PRINCIPAL OCCUPATION

\begin{tabular}{|c|c|c|c|c|c|c|c|c|}
\hline Specification of Area & A & B & $\mathrm{Q}$ & $D$ & $\mathrm{E}$ & $\mathrm{F}$ & G & Total \\
\hline $\begin{array}{l}\quad \text { Total } \\
\text { Cane Cutter } \\
\text { Weight man } \\
\text { Hoer } \\
\text { Cane cleaner } \\
\text { Exchange man } \\
\text { Squad Leader } \\
\text { Oxcart Driver } \\
\text { Assistant Driver } \\
\text { Ax man } \\
\text { Motorist } \\
\text { Coachman } \\
\text { Driver of Pack Animals } \\
\text { Watchnan } \\
\text { Mason } \\
\text { Herdsman } \\
\text { Hay Cutter } \\
\text { Military Police } \\
\text { Tractor Driver } \\
\text { Stable man } \\
\text { Knife Sharpener } \\
\text { Carperter } \\
\text { Administrator } \\
\text { Other }\end{array}$ & $\begin{array}{l}100,0 \\
(113) \\
31,8 \\
15,8 \\
1,8 \\
6,2 \\
10,6 \\
2,7 \\
3,5 \\
-- \\
-- \\
0,9 \\
1,8 \\
1,8 \\
2,7 \\
1,8 \\
0,9 \\
-- \\
-- \\
2,7 \\
0,9 \\
0,9 \\
-- \\
-- \\
13,2\end{array}$ & $\begin{array}{l}100,0 \\
(98) \\
45,9 \\
18,4 \\
3,1 \\
=1,0 \\
3,1 \\
1,0 \\
-1,0 \\
3,1 \\
-1,0 \\
1,0 \\
-- \\
-- \\
\overline{4}, 1 \\
1,0 \\
\overline{1}, 0 \\
3,1 \\
\overline{12} \\
12\end{array}$ & $\begin{array}{c}100,0 \\
(114) \\
6,1 \\
42,8 \\
19,3 \\
13,2 \\
4,4 \\
1,8 \\
0,9 \\
- \\
0,9 \\
0,9 \\
-- \\
-- \\
-- \\
-- \\
-- \\
0,9 \\
-= \\
-- \\
-- \\
=- \\
-- \\
0,9 \\
7,9\end{array}$ & $\begin{array}{c}100,0 \\
(22,4) \\
39,4 \\
24,2 \\
1,3 \\
3,6 \\
8,0 \\
1,3 \\
1,8 \\
2,2 \\
1,8 \\
1,3 \\
1,3 \\
0,9 \\
0,9 \\
0,9 \\
02,2 \\
-0,4 \\
0,4 \\
0,4 \\
0,4 \\
0 \\
3,3\end{array}$ & $\begin{array}{c}100,0 \\
(116) \\
26,6 \\
4,3 \\
31,8 \\
14,7 \\
2,6 \\
-- \\
0,9 \\
6,0 \\
-- \\
0,9 \\
0,9 \\
-- \\
-- \\
2,6 \\
1,7 \\
-- \\
-- \\
-- \\
-- \\
-- \\
-- \\
0,9 \\
6,1\end{array}$ & $\begin{array}{c}100,0 \\
(89) \\
12,4 \\
7,9 \\
48,4 \\
4,5 \\
-3,4 \\
1,1 \\
1,1 \\
-= \\
=- \\
-- \\
-- \\
4,5 \\
1,1 \\
-- \\
-- \\
-- \\
-- \\
1,1 \\
1,1 \\
-- \\
2,2 \\
7,8\end{array}$ & $\begin{array}{c}100,0 \\
(94) \\
21,3 \\
35,0 \\
7,4 \\
2,1 \\
5,3 \\
5,3 \\
1,1 \\
-- \\
4,3 \\
-2,1 \\
3,2 \\
-- \\
=- \\
3,2 \\
-- \\
1,1 \\
-- \\
1,1 \\
-- \\
-- \\
-- \\
7,5\end{array}$ & $\begin{array}{r}100,0 \\
(848) \\
28,1 \\
21,7 \\
13,8 \\
6,3 \\
5,2 \\
2,2 \\
1,5 \\
1,5 \\
1,2 \\
1,1 \\
0,9 \\
0,9 \\
0,9 \\
0,9 \\
0,7 \\
0,7 \\
0,6 \\
0,6 \\
0,5 \\
0,5 \\
0,5 \\
0,5 \\
8,6\end{array}$ \\
\hline
\end{tabular}

Tongalves; 1966:128)

Note (Table II) that of the persons who ame 10 years old or more, less than half (49.2\%) maintain a wage paying occupation.

Practically ali the occupations listed are connected to the acricultural industry of sucar. The first five jobs, in fact, comprise at least $60 \%$ of the persons holding wage paying occupations. 
TABIE III

GENERAI HOUSING CONDITIONS

\begin{tabular}{|c|c|c|c|c|c|c|c|c|}
\hline Specification of Area & $A$ & $B$ & $\mathrm{C}$ & $\mathrm{D}$ & $\mathrm{E}$ & $F$ & G & Total \\
\hline $\begin{array}{l}\text { Total Number of Houses } \\
\text { Area of Occupation } \\
\text { Om } \\
\text { Rent } \\
\text { Given by Employer } \\
\text { Given by Others } \\
\text { Construction Material }\end{array}$ & $\begin{array}{c}100,0 \\
(61) \\
- \\
100,0 \\
-\end{array}$ & $\begin{array}{c}100,0 \\
(59) \\
- \\
\overline{96,6} \\
3,4\end{array}$ & $\begin{array}{r}100,0 \\
(59) \\
42,4 \\
3,4 \\
50,8 \\
3,4\end{array}$ & $\begin{array}{r}100,0 \\
(120) \\
5,8 \\
2,5 \\
90,9 \\
0,8\end{array}$ & $\begin{array}{c}100,0 \\
(59) \\
-3,4 \\
96,6 \\
=-\end{array}$ & $\begin{array}{r}100,0 \\
(59) \\
20,3 \\
8,5 \\
67,8 \\
3,4\end{array}$ & $\begin{array}{c}100,0 \\
(60) \\
11,7 \\
8 \overline{6}, 6 \\
1,7\end{array}$ & $\begin{array}{r}100,0 \\
(477) \\
10,7 \\
2,5 \\
85,1 \\
1,7\end{array}$ \\
\hline $\begin{array}{l}\text { Brickwork } \\
\text { with plaster } \\
\text { Lath } \\
\text { and plaster } \\
\text { Other } \\
\text { Ploor }\end{array}$ & $\begin{array}{r}6,6 \\
45,8 \\
36,1 \\
11,5 \\
-\end{array}$ & $\begin{array}{r}8,5 \\
44,1 \\
35,6 \\
11,8 \\
--\end{array}$ & $\begin{array}{c}25,4 \\
45,8 \\
18,6 \\
10,2 \\
\ldots\end{array}$ & $\begin{array}{r}13,3 \\
25,8 \\
36,7 \\
22,5 \\
1,7\end{array}$ & $\begin{array}{c}22,0 \\
49,2 \\
23,7 \\
5,1 \\
--\end{array}$ & $\begin{array}{r}6,8 \\
35,6 \\
45,7 \\
11,9 \\
--\end{array}$ & $\begin{array}{r}5,0 \\
56,6 \\
20,0 \\
16,7 \\
1,7\end{array}$ & $\begin{array}{r}12,6 \\
41,1 \\
31,7 \\
14,0 \\
0,6\end{array}$ \\
\hline $\begin{array}{l}\text { Brick } \\
\text { Cement } \\
\text { Dirt } \\
\quad \text { Roof }\end{array}$ & $\begin{array}{l}11,5 \\
24,6 \\
63,9\end{array}$ & $\begin{array}{l}33,9 \\
20,3 \\
45,8\end{array}$ & $\begin{array}{l}3:, 2 \\
2: 4 \\
4: 4\end{array}$ & $\begin{array}{l}18,3 \\
15,0 \\
66,7\end{array}$ & $\begin{array}{r}50,8 \\
6,8 \\
42,4\end{array}$ & $\begin{array}{l}20,3 \\
30,5 \\
49,2\end{array}$ & $\begin{array}{l}15,0 \\
11,7 \\
73,3\end{array}$ & $\begin{array}{l}24,9 \\
18,7 \\
56,4\end{array}$ \\
\hline $\begin{array}{l}\text { Tile } \\
\text { Galvanized sheet } \\
\text { Zinc } \\
\text { Other }\end{array}$ & $\begin{array}{c}96,7 \\
-- \\
0,3 \\
--\end{array}$ & $\begin{array}{c}96,6 \\
1,7 \\
-1,7\end{array}$ & $\begin{array}{r}94,9 \\
5,1 \\
\cdots \\
\cdots\end{array}$ & $\begin{array}{r}95,0 \\
0,8 \\
1,7 \\
2,5\end{array}$ & $\begin{array}{c}100,0 \\
=- \\
--\end{array}$ & $\begin{array}{l}98,3 \\
1,7 \\
-- \\
--\end{array}$ & $\begin{array}{l}95,0 \\
5,0 \\
--\end{array}$ & $\begin{array}{l}96,5 \\
1,9 \\
0,8 \\
0,8\end{array}$ \\
\hline
\end{tabular}

(Gongalves; 1966:129) 
TABLE IV

APPIICATION OF SAIAARY

\begin{tabular}{lrrrrrrrrr}
\hline Specification of Area & A & B & C & D & E & $F$ & $G$ & Total & Percent \\
\hline Total of Families & 61 & 59 & 62 & 120 & 59 & 59 & 60 & 477 & \\
Food & 1,600 & 1,446 & 1,352 & 2,740 & 1,466 & 1,113 & 1,390 & 11,107 & $80.7 \%$ \\
Rent & -- & -- & -- & 4 & -- & -- & -- & 4 & \\
Fuel & 31 & 25 & 20 & 70 & 22 & 26 & 26 & 220 & \\
Light & -1 & -- & 3 & -- & -- & -- & -- & 3 & \\
Water & 1 & -- & -- & -- & 2 & -- & -- & 3 & \\
Medicine & 67 & 114 & 80 & 194 & 48 & 94 & 35 & 632 & $4.4 \%$ \\
Sanitary Products & 77 & 53 & 63 & 93 & 65 & 54 & 47 & 452 & $3.2 \%$ \\
Education & 1 & 4 & 2 & 7 & 6 & 6 & 2 & 28 & \\
Clothing & 105 & 86 & 61 & 241 & 38 & 77 & 36 & 644 & $4.5 \%$ \\
Smoke and Drink & 99 & 71 & 110 & 141 & 69 & 33 & 74 & 597 & $4.3 \%$ \\
Other Expenses & 9 & 13 & 14 & 73 & 8 & 12 & 7 & 136 & \\
$\quad$ Total & 1,990 & 1,812 & 1,705 & 3,563 & 1,724 & 1,415 & 1,617 & 13,826 & \\
\hline
\end{tabular}

(Goncalves; 1966:152) 